\title{
Disability: A personal odyssey
}

Joseph M. Camilleri

This is an author produced version of a paper published in Disability \& Society. This paper has been peer-reviewed but does not include final publisher proof-corrections or journal pagination.

Citation for the publisher paper

Joseph M. Camilleri (1999) Disability: A personal odyssey, Disability \& Society, 14:6, 845-853,

https://doi.org/10.1080/09687599925939 


\title{
Disability: A personal odyssey
}

\author{
JOSEPH M. CAMILLERI
}

Kummissjoni Nazzjonali Persuni b’Dizabilita' , Centru Hidma Socjali, Triq II-Kbira San Guzepp, Sta. Venera HMR 18, Malta

\section{Introduction}

A person having an impairment is not, ipso facto, a disabled person. Indeed, I know many highly intelligent, highly qualified, charming people with impairments who are just that: people with impairments, not persons with disability. That is to say they do not perceive themselves as persons with disability. Disability for me has come to mean, not so much dwelling within a biologically impaired body, as a sense of self-ownership. Ultimately, defining myself as a person with disability implies never being apologetic about my differences, but valuing them as intrinsic elements of myself that I am proud of.

Heady stuff, I can hear some of you say. However, before I'm accused of making facile statements, or, still worse of succumbing to rampant narcissism, let me state that being unapologetic in the face of my very obvious physical difference and weakness has been one of the most difficult processes of adaptation I have ever had to undergo. I would rate it as second only to adjusting to married life; but then we're not here to go into that today!

\section{Through the Looking Glass}

A group of us, disabled and non-disabled people, were discussing the different definitions of disability when a disabled colleague of mine made this dry observation: 'Call me Rudolf Valentino: I' II still never tango!' I understood what he meant, but he was still wrong. What we call ourselves, and what society calls us is fundamental to the way we are perceived, fundamental to our dignity as human beings, and in some situations vital to our very existence. It was clear to me that notwithstanding my friend's considerable achievements in the 'big' world, they were all based on a denial of his disabled self. I could understand him, because I have been there myself.

Although I have had physical impairments for 43 years, that is since the age of 2 years and 5 months, I cannot say that I have perceived myself as a disabled person for that long. Throughout my 
formative years and into most of my adult life I was schooled to categorise myself, to develop an image of myself, as a person severely lacking in many of the basic characteristics which set us apart as human beings. For most of my life I have been influenced by educators, media images, religious instruction and especially by the everyday, negative responses of individuals in all walks of life, to see myself as somehow 'lesser' than anyone non-disabled.

Being labelled 'handicapped', 'impaired', 'less fortunate' in our society has, at different parts of my life, led to feelings of shame, sinfulness, diminishment, dehumanisation; that I was an abhorrent 'freak' of nature, a burden on the people who love me. For years, my thoughts and actions were coloured by the belief that my physical difference was the permanent cause of all my problems. In their turn, these feelings led to me to hope for the obvious solution: a miracle. Later, in the absence of divine resolution, I developed a single-minded ambition to expiate some vague wrong, committed by virtue of my very existence.

I learnt very early on in my life that if I wanted to be perceived as a success in the 'normal' world, I would have to live a lie. I would have to pretend that my impairment did not exist or, at the very least, did not matter. Never must I ask for allowances to be made on the basis of my impairment. Even when I was praised as a 'success', it was always for having 'broken through' for having succeeded in approximating 'normal' existence. For having convincingly aped my 'betters'. Praise, in other words, for somehow having denied or negated part of my very essence --my difference.

By the time I began my studies at the University of Malta I was already a graduate Achievement Syndrome. I was generally regarded as a 'heroic' character with an indomitable will, someone who succeeded 'in spite of' incalculable odds. However, whereas, I had become something of a 'supercripple', up to this point I the image I had of myself was still impairment driven.

I had always felt uncomfortable with the 'achievement' stereotype, but could never find an alternative I was happy with. Achievement Syndrome meant that I had to immerse myself in the world of the non-disabled and never, absolutely never, be seen in the company of disabled fellows. I knew instinctively that to be seen in the company of other disabled persons especially people with an intellectual disability meant being associated with failure, weakness, with 'otherness'. It meant being talked down to, patronised and never taken seriously. It threatened to erode the high degree of 
acceptance which I had carved out for myself and on my own merits. Achievement syndrome ultimately condemned me to being an outsider, of never really belonging to either the disabled or non-disabled worlds. The irony was that I didn't want to belong to either world. I wanted to be a part of both of them.

Achievement syndrome is what robs disabled persons of many of our best educated, most dynamic individuals, leaving us leaderless, voiceless and powerless in the face of stronger, more numerous and more well-established groups.

In 1989, I was invited to visit Sweden and experience life specifically as a disabled person. By a happy coincidence, I made contact with our own recently established National Commission Persons with Disability. That chance encounter was to lead me to a better knowledge of myself and a new-found sense of pride in my disabled self. In retrospect, I can say that it is strange that matters transpired as they did. For by that time I had had my impairment for 35 years and felt that there was little that anyone could teach me about the subject of Disability still less by non-disabled persons. A case of inverted snobbery? Perhaps.

However, in my eagerness to be accepted in the non-disabled world I had turned my back on all the exciting developments that had been taking place in the Disability: a personal odyssey 847 world of Disability. The struggles for self-determination and civil rights in the US, UK and other countries, the numerous international declarations on various aspects of our lives, the energetic, sometimes contentious discussions focusing on issues (not impairments) and ultimately, the `struggle of disabled people to exercise control over the services, policy and decision-making which shapes and determines [our] quality of life' had all passed me by. The disability world-picture had changed radically from my memory of it as a pathetic, charity-based, infantile existence.

Even so it would take Fred Bezzina, then Executive Director of the Commission and himself the parent of a child with a disability, another 5 years to convince me to 'move' full-time into the world of Disability. Even then I still perceived such a move as an admission of failure. In due course, my involvement with the Commission on a voluntary basis, the reading I had to undertake in order to prepare myself for various activities and, especially, discussions and arguments with various friends would also be instrumental in helping me to value my disabled self, while rejecting the idealised, airbrushed counterfeit that is still today the acceptable face of disability. 
I was not suddenly struck by a lightning bolt of revelation, nor was I instantly transformed by some internal epiphany. The journey towards 'conscientisation' has been very long and arduous. More often than not the whole process was in danger of running afoul of powerful emotions like doubt, fear and self-loathing. I came to see the truth of Paolo Freire's assertion that: '[conscientisation] is a painful business, it is disturbing in its beginning as if we were born again' (Freire, 1977, p. 224).

Many people fear the idea of inclusive education. Many people are unhappy at the thought that children with disabilities should receive their education in mainstream. They fear inclusive education as the destroyer or the dismantlement of the educational system as we know it. In it, they see the abandonment of standards and the ushering in of a utopian (in the most pejorative sense) laissez-faire approach. These are very real fears. Fears that will not go away. We must confront them with understanding and determination; we must accept that the change we want to bring about will only take place gradually and laboriously, but we must begin, and having begun we will have to persevere.

It has been difficult for me to arrive at a new understanding of my own human condition. Difficult, even though I have had first-hand experience of the ups and downs of living with disability, I have experienced life-threatening situations, I have had time to read and reflect. Even then, I only truly adopted the reality of being disabled person after almost 42 years. If I struggled so hard against the acceptance of my own reality, then who am I to condemn a teacher in a mainstream class who sees inclusive education as a harbinger of Armageddon?

My own journey towards a more liberating perception of myself began with an attempt to understand the meaning of the word 'Disability'. As I said earlier, my friend took the attitude that definitions were no more than 'words, words, words'. I have come to understand however, that:

How disability is defined is of crucial importance. The presuppositions informing particular definitions can be offensive and provide the basis of stereotyping and stigmatisation. (Barton, 1993.) 


\section{Defining Disability}

We are seen as 'abnormal' because we are different, we are problem people, lacking the equipment for social integration. But the truth is, like everybody else, we have a range of things we can and cannot do, a range of abilities both mental and physical that are unique to us as individuals. The only difference between us and other people is that we are viewed through spectacles that only focus on our inabilities... (Brisenden, 1986.)

The common assumptions about disability focus on our lack of abilities. The negative terms most frequently used to describe us: crippled, handicapped, less fortunate, all accentuate our postlapsarian imperfections compared with our (presumably) more 'blessed' brethren. We are, in a word, 'in valid'. Even more politically correct designations, such as, 'differently challenged', impaired, etc., accent our apartness, our dislocation from the common herd. At best we have 'special' needs and, for our own good, we have to be cared for by trained specialists and kept in segregated environments: at home, in special schools, in day care centres, in institutions.

Many negative attitudes we have had to face have developed as a direct result of society's morbid fascination with our biological differences. For the sake of argument, let me simplify and select a few key elements which have contributed greatly to our being devalued. High among these negative factors I would have to cite socio-religious attitudes, industrialised society's insistence on standardisation (or 'normalisation'), the work ethic which only values people in terms of their degree of production and the medical concept of 'rehabilitation'.

In societies like ours, where religion has been the nucleus of daily life, literal interpretations of the scriptures have tended to equate disability with the presence of sin, whether it is within the individual only, or also within the family. Such was the case in my childhood, when I first developed my condition. The family as a unit would soon develop an overpowering sense of shame, stigma, pollution and failure. Even if parents, like my own, decided to defy their community's attitude, the sense of physical and moral bankruptcy was not exorcised, but merely lay below the surface, eating away at the quality of life of every individual member. 
Clearly, the growth of industrialised processes with their emphasis on the concept of standardisation, of both the end result and the means of production, has also had a negative impact on the acceptance of difference. Machines that were uniform in structure required equally uniform human shapes to run them; people who were almost identical in height, build, strength, intelligence. People who conformed to these normative values were labelled 'normal', while those who did not were deemed 'abnormal' and aggressively rejected.

The work ethic which values a human being in terms of his, or her, ability to produce has also had an active part in the development of negative stereotypes. The most brutal approach contends that people who do not produce sufficiently, in the general understanding of the term, are useless parasites fit only for extermination.

The invalid is a parasite on society. In a certain state it is indecent to go on living. To vegetate on in cowardly depen Disability: a personal odyssey 849 medicaments after the meaning of life, the right to life, has been lost ought to entail the profound contempt of society. (Nietzsche.)

Such assertions by Frederick Nietzsche, amongst others, would eventually lead to the wholesale slaughter of people like myself in many different countries, including Nazi Germany.

A more human approach advocated the utopia of an institutionalised life where our 'special' needs are taken care of by highly trained professionals. The belief that our existence should be lived out in a hospital environment has proven such a compelling argument, such a seemingly ready-made solution to the social 'problem' of disability that it lives on today even in Malta.

\section{The Medical Model: 'like a patient aetherised on a table'?}

The medical profession set itself, and was set, the task of solving the 'problem' of long-term care of disabled people by seeking ways to make us conform to the norm and to make us productive. Based on a functional, positivist view of human beings, a myriad of rehabilitative programmes were developed world-wide. Whereas each one may have varied in its methods, the presumption underlying each and every one of them was the same: we were imperfect as we were and needed to be 'fixed'. To make people move, communicate, think, behave according to established patterns. 
Over the years, the medical model of disability has presented society with a ready-made formula by which to judge or rather misjudge, us. Based as it is on positivist assumptions and seemingly objective assessments, the medical model of disability has been instrumental in creating several myths about us.

Thus, the medical model of disability:

- sees disability as specialised, medical condition requiring the intervention of suitably skilled and qualified professionals;

- has created a market for the development of vast arrays of 'specialised' professionals in various fields (often, very lucrative fields) who put themselves forward as the only people having the necessary qualifications and skills to provide for our 'special' needs;

- fosters the fallacy that our needs are 'special' or somehow different from everyone else's;

- sees disabled persons and their families as passive recipients of care, patients who have no informed opinions and who therefore need not be consulted over matters which directly concern them;

- focuses on a purely functional assessment, highlighting inabilities, while ignoring less manifest abilities;

- sees disability as a perversion of the human condition, a tragedy for the individual;

- further implies that it is the duty of both disabled persons and their families to seek 'normalisation' through a striving after cures (medical and miraculous) and rehabilitation programmes no matter how laborious, time- consuming, expensive or futile these may be;

- does not advocate a change in social structures but a seeking after ad hoc solutions for the individuals, often involving the exercise of charity;

- decrees that where all attempts at 'normalisation' have failed, the individual should be segregated from society in 'special' conditions, like special schools, institutionalised residential homes, hospitals.

Having been on the receiving end of most of these assumptions I can personally vouch for the fact that the medical model had, and still has very strong roots and far reaching consequences. For example, in the 1970-80s, even though the United Nations was responding to a growing call for the 
recognition of disabled persons' civil rights, the definitions of disability which the organisation adopted as its international norm were (a) developed by non-disabled persons, i.e. the World Health Organisation and (b) the definitions were informed by the Medical Model of disability.

Central to the UN, WHO definitions is the assumption that persons with disability are passive objects. By 1981, when these definitions came into widespread use as a result of the International Year of Persons with Disability, politically conscious disabled activists had already begun the process of discrediting and rejecting the Medical Model of Disability, and therefore the very foundations upon which the UN was building its disability policies.

\section{The Social Model of Disability: towards self-realisation}

To trace the emergence of disability activism we have to look back to other examples of mouldbreaking, civil rights-inspired activities. The startling similarities between a segregationist/apartheid mentality which discriminates against black people and the systematic policies of exclusion which society sanctions in respect of people like myself has meant that the Black American Civil Rights Movement of the 1950-60s, can be traced as the paradigm of all later civil rights struggles.

Also in the USA in the 1960s, the Consumer Movement highlighted the issue of choice. The movement empowered our thinking by introducing us to the idea of the disabled person as an active consumer of services, one who makes choices and by extension someone who exercises power over service providers. This attitude is in stark contrast to the view of disabled persons and their families as passive recipients of services.

In the 1970s, the Women's Movement inspired disabled people to reassess the way we looked at ourselves. The rejection of society's assumptions of our collective value, which was often based solely on our body image, would by systematically challenged and rejected in favour of a more politically conscious, more empowering perceptions.

The single most powerful group of disabled persons in the USA to reject society's negative perceptions of them were young Vietnam Veterans, who rebelled against society's glorifying of their previous unimpaired youth, and its subsequent rejection of them as 'hopeless cripples'. Unlike myself, these young men had not been indoctrinated into a sense of inferiority. They were outraged at the 
thought of Disability: a personal odyssey 851 having to live a life of dependency. Their vociferous calls for equal rights led to the insertion of section 504 in the 1973 Rehabilitation Act. This was 'a one sentence statement prohibiting discrimination against "otherwise qualified handicapped" individuals " under any program or activity receiving Federal financial assistance" Because of this section's farreaching implications, the 1973 Rehabilitation Act has sometimes been called $\underline{a}$ the Civil Rights Act of the handicapped"' (DeJong, 1993).

Emboldened by these tangible successes, physically impaired individuals in the USA began demanding more control over their lives, these common aspirations were encapsulated in what would become known as the Independent Living Move- ment.

In early 1970s, the IL movement gained greater visibility and momentum with the creation of the Center for Independent Living (CIL) in Berkeley, California. The Berkeley CIL incorporated itself in 1972 as a self-help group to be managed primarily by persons who were themselves disabled. (DeJong,

The primary tenet of the movement was that disabled people were to take control of their own lives: they were to be the sole decision makers in all matters which affected them. The United Nations was to enshrine many of the principles which motivated the Independent Living Movement in its 1975 Declaration of Rights of Disabled Persons.

In the United Kingdom, also in 1975, another group of physically impaired people rebelled against the imposed passivity.

We as a Union are not interested in descriptions of how awful it is to be disabled. What we are interested in is the ways of changing our conditions of life, and thus overcoming the disabilities which are imposed on top of our physical impairments by the way society is organised to exclude us. (UPIAS, 1976, pp. 4-5.)

The significance of the social model of disability lies in its radical challenge to the medical or individual model of disability. The latter is based on the assumption that the individual is 'disabled' by their impairment, whereas the social model of disability reverses this causal chain to explore how socially constructed barriers (for example, in the design of buildings, modes of transport and communication, 
and discriminatory attitudes) have 'disabled' people with a perceived impairment (Barnes \& Mercer, 1996).

The United Nations' continuing involvement in disability issues has seen a growing awareness worldwide that Disability is indeed more of a social, rather than a medical issue. Between 1981 and 1994 the UN has highlighted the cause of disabled persons with the publication of two central documents: The World Pro- gramme of Action (United Nations, 1988) and the Standard Rules on the Equalisation of Opportunities for Persons with Disability (United Nations, 1994). The development of thought away from medically informed perceptions of disability to a view of disability as primarily a social construct is clearly apparent. This has meant that crucial anti-discriminatory legislation like the landmark American with Disabilities Act (1990) focuses on the removal of social and cultural barriers and the accentuation of individual empowerment. Our own Equal Opportunities (Persons with Disability) Bill, once enacted into law, will doubtlessly spur us forward towards greater self-realisation.

\section{Conclusions}

I mentioned earlier my own personal odyssey towards self-awareness. I have not written about what made it possible. The single most powerful tool I have taken with me has been my education; my education in the mainstream. An education which taught me to look upon myself as an inheritor, not as someone who was 'other' and 'apart'. I did not feel any different from my non-disabled peers until society taught me that if gender-based discrimination is primarily based on negative social perceptions, discrimination against disabled persons is based on the concept of our being intrinsically less. If anyone doubts the truth of this, I stand before you today as a living example of the truth of my assertion.

\section{Acknowledgements}

An earlier version of this presentation delivered at a 1-day seminar: 'Inclusive Education: towards a pedagogy of success for all'. The University of Malta, Faculty of Education in association with the Kummissjoni Nazzjonali Persuni b' Disabilita' , Friday, 25th September, 1998, at the Seabank Hotel, Mellieha.

Joe Camilleri is a disabled person and Chairman of the Kummissjoni Nazzjonali Persuni b'Dizabilita' 


\section{REFERENCES}

BARNES, C. \& MERCER, G. (1997) Breaking the Mould? An introduction to doing disability research, in: BARNES, C. \& MERCER , G. (Eds). Doing Disability Research, Vol. 1, pp. 1-4 (Leeds, The Disability Press).

BARTON, L. (1993) Disability and special educational needs: some perennial European concerns, Education (Malta), 5(1), pp. 17-22, paper presented at a National Conference on Special Education, Malta, 25th June, 1993.

BARTON, L. (1998) Teachers, change and the struggle for inclusive education, a paper presented at the Annual General Conference of the Malta Union of Teachers, 1-3 June, 1998, Malta.

BEZZINA, F. (Ed.) (1993) Special Education in Malta: National Policy (Kummissjoni Nazzjonali Persuni b' Dizabilita', Malta).

BRISENDEN (1986) cited in BARTON, L. Disability and special educational needs: some perennial European concerns, Education (Malta), 5(1), pp. 17士22, paper presented at a National Conference on Special Education, Malta, 25th June, 1993.

CAMPBELL, J. \& OLIVER, M. (1996) Disability Politics: understanding our past, changing our future (London, Routledge).

CENTRE FOR STUDIES IN INCLUSIVE EDUCATION (1996) What is Inclusion? (Bristol, CSIE): Centre for Studies in Inclusive Education (CSIE): 1, Redland Close, Elm Lane, Redland, Bristol BS6 6UE, UK. (Email: 100432.3417@compuserve.com).

CENTRE FOR STUDIES IN INCLUSIVE EDUCATION (1997) Inclusive Education: a framework for change. National and international perspectives (Bristol, CSIE).

DEJONG, G. (1993) Defining and Implementing the Independent Living ConceptCrewe, in ZOLA, I.K. (Eds) Independent Living for Physically Disabled People (Jossey-Bass Publishers). 
DEPARTMENT FOR EDUCATION AND EMPLOYMENT (1997) Excellence for All Children: meeting special educational needs, a Green Paper (London, DEE).

EUROPEAN COMMISSION (1996) Helios II -European Guide of Good Practice Towards Equal Opportunities for Disabled People.

FREIRE, P. (1977) A few notions about the word 'concientization', in: DALES, S., et al. (Eds) Schooling and Capitalism, pp. 224-227 (Buckingham, Open University Press.).

MORRIS, J. (Ed.) (1993) Pride Against Prejudice. Transforming Attitudes to Disability (London, The Women's Press).

OLIVER, M. \& BARNES, C. (1998) Disabled People and Social Policy: from exclusion to inclusion (London, Longmans).

SWAIN, J. et al. (Eds) (1993) Disabling Barriers-enabling environments (London, Sage Publications).

UNITED NATIONS (1998) World Programme of Action Concerning Disabled Persons.

UNITED NATIONS (1993) The Standard Rules on Equalisation of Opportunities for Persons with Disabilities (A/RES/48/96), United Nations Resolution adopted by the General Assembly at its 48th session on 20th December, 1993.

WORLD CONFERENCE ON SPECIAL NEEDS EDUCATION (1994) The Salamanca Statement and Frame- work for Action on Special Needs Education (World Conference on Special Needs Education: Access and Quality, Salamanca, Spain, 7 \pm 10 June, 1994). 